\title{
The Effectivity of pH 4 Emulsion on Skin Barrier Function in The Elderly: A Systematic review and meta-analysis
}

\author{
Milka Wulansari Hartono*, Diah Adriani Malik, Retno Indar Widayati, Asih Budiastuti, Puguh \\ Riyanto, Muslimin \\ Department of Dermatovenereology, Faculty of Medicine, Diponegoro University / Dr. Kariadi \\ Hospital, Jalan Dr. Sutomo No. 16 Semarang, Indonesia.
}

\section{ABSTRACT}

Background: The $\mathrm{pH}$ of the skin surface is elevated in the el${ }^{*}$ Correspondence to Author: derly therefore it may cause impaired barrier function manifest Milka Wulansari Hartono as various cutaneous abnormalities, including xerosis, pruritus, dermatitis, and skin infections. Consequently, skin care products for the elderly should contain moisturizing ingredients which are formulated to normalize the skin surface $\mathrm{pH}$. Application of $\mathrm{pH}$ 4 emulsion is potentially beneficial to improve barrier function in the elderly and promoting skin health. We aimed to determine the difference of effectiveness of $\mathrm{pH} 4$ emulsion compared to identical non $\mathrm{pH} 4$ emulsion on decreasing TEWL in the elderly. A systematic review and meta-analysis was performed of randomized clinical trials assessing the effects of $\mathrm{pH} 4$ emulsion on skin barrier function in the elderly.

Methods: Medline Pubmed, Scopus, ProQuest, Cochrane library, ClinicalTrials.gov, the reference list, conference proceedings, researchers in the field of eligible studies were searched. Four studies ( $n=98$ subjects) were included in qualitative analysis of which two studies ( $n=45$ subjects) were included in the meta-analysis. The mean age of the participants was 71.1 years old.

Interventions use the application of $\mathrm{pH} 4$ water in oil emulsion $(n=2)$ and $\mathrm{pH} 4$ oil in water emulsion $(n=2)$. Duration of intervention (24 hours-7 weeks) and outcomes of interest varied among included studies.

Department of Dermatovenereolog$y$, Faculty of Medicine, Diponegoro University / Dr. Kariadi Hospital, Jalan Dr. Sutomo No. 16 Semarang , Indonesia.

Email:milkakulkel@gmail.com

How to cite this article:

Milka Wulansari Hartono, Diah Adriani Malik, Retno Indar Widayati, Asih Budiastuti, Puguh Riyanto, Muslimin. The Effectivity of $\mathrm{pH} 4$ Emulsion on Skin Barrier Function in The Elderly: A Systematic review and meta-analysis. American Journal of Dermatological Research and Reviews, 2021; 4:40

Results: Pooling of data using random-effects model found lower TEWL score in the $\mathrm{pH} 4$ emulsion than in non $\mathrm{pH} 4$

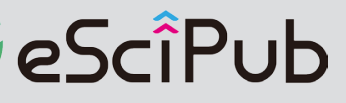

eSciPub LLC, Houston, TX USA. 
emulsion, with no significant difference (overall effect mean difference $-0.068,95 \%$ confidence interval $-0.485-0.348, p=0.11, \mathrm{l}^{2}=60.1$, two RCTs). In addition to that, the qualitative analysis found that the application of $\mathrm{pH} 4$ emulsion increased stratum corneum hydration, decreased skin surface roughness and scaliness, decreased DASI, and improved ICLL length and lamellar organization.

Conclusion: The meta-analysis result of the mean differences of TEWL scores lowering effect between $\mathrm{pH} 4$ emulsion and non $\mathrm{pH} 4$ emulsion is statistically inconclusive. This is despite the observation that the $\mathrm{pH} 4$ emulsion appears to be more effective comparatively. The qualitative analysis found that the application of $\mathrm{pH} 4$ emulsion had improved skin barrier function in the elderly. Larger scale, well-designed RCTs assessing the effects of $\mathrm{pH} 4$ emulsion on skin barrier function in the elderly, are still needed.

Keywords: pH 4 emulsion; Skin barrier elderly

\section{Abbreviations:}

TEWL: Trans Epidermal Water Loss

RCT: Randomized Controlled Trial

DASI: Dry skin Area and Severity Index

ICLL: Intercelullar Lipid Lamellae

Mesh: Medical subject headings

PRISMA: Preferred Reporting Items for Systematic Review and Meta-Analysis

TEM: Transmission Electron Microscopy

HPTLC: High Performance Thin Layer Chromatographic

\section{Introductions}

According to United Nations World Population Ageing, the population above 60 years old is referred to as the old age or elderly population.

[1] With advances in medical and healthcare technology, human lifespans are increasing and the study predicts that the elderly population will exceed the number of young populations by 2050. [1]

Aging skin displays structural and functional skin barrier changes. ${ }^{\text {2] }}$ Stratum corneum plays a role as the epidermal skin barrier, "brick and mortar" model, to prevent insensible water loss from the skin surface (TEWL), prevent the entry of external molecules and microorganisms. According to the "brick and mortar" concept, the corneocytes act as "the bricks" surrounded by intercellular lipid lamellae ("the mortar") and attached by corneodesmosome ("the rivets"). [3] The normal skin surface $\mathrm{pH}$ is slightly acidic, ranging from $4.5-5.3 .{ }^{[4]}$ This acidic $\mathrm{pH}$ of the skin maintains functions of the skin such as cohesion of stratum corneum, epidermal barrier homeostasis, and antimicrobial defense. In elderly people, however, the skin surface $\mathrm{pH}$ becomes less acidic, ranging from 5.0-6.0. ${ }^{[5]}$ It may cause impaired barrier function to manifest as a variety of cutaneous abnormalities, including xerosis, pruritus, dermatitis, and skin infections. TEWL measurement is very important and is commonly used as an instrument to measure the effect of various cosmetic products and the skin barrier function.

Evidence suggests the importance of skin 
emolliating and moisturizing in elderly skin to maintain healthy skin in elderly people. Because of the importance of skin surface $\mathrm{pH}$ regulation, skin care products for the elderly should contain moisturizing ingredients which are also formulated to normalize the skin surface $\mathrm{pH}$. [6] Several studies suggested acidifying aged skin with an acidic $\mathrm{pH}$ to improve skin health in the elderly. ${ }^{[7]}$

There has never been systematic reviews and meta-analysis assessing the effects of $\mathrm{pH} 4$ emulsion on skin barrier function in the elderly. Therefore, we conducted a systematic review and meta-analysis evaluating the efficacy of the application of $\mathrm{pH} 4$ emulsion on skin barrier function in the elderly. TEWL measurement was chosen to determine skin barrier function improvement.

\section{Methods}

\section{Literature Search}

The following databases were searched until the time of data analysis: Medline Pubmed, Scopus, ProQuest, Cochrane library, ClinicalTrials.gov. The reference list, conference proceedings, researchers in the field of eligible studies were searched to identify additional studies.

The following Mesh terms were used for searching: "pH emulsion" AND "skin barrier elderly". A literature search was performed by three reviewers independently using PRISMA flow diagram 2009. [8] Differences in opinion were resolved between all reviewers to reach consensus.

Inclusion criteria were: clinical trials with/without randomization from 2011 until 2020, participants mean age $\geq 60$ years, intervention: $\mathrm{pH} 4$ emulsion application to the elderly skin, participants did not have any dermatitis or skin inflammation at the test area, participants did not have systemic diseases, outcomes: TEWL score. Studies were excluded if they: were written neither in Indonesian nor English, were case report, serial case, letter, literature review.

\section{Study Selection}

Three reviewers conducted the study selection independently. Duplicate articles were removed. Title and abstract review, full-text review were assessed for eligibility using the predefined inclusion and exclusion criteria. Differences in opinion were resolved between all reviewers to reach a consensus.

\section{Data extraction}

Data extraction was performed independently by three reviewers using The Cochrane Collaboration data collection form for RCTs only. [9] Differences in opinion during data extraction were resolved between all reviewers and consensus was reached.

\section{Assessment of risk of bias}

Risk-of-bias assessment was performed independently by three reviewers using The Cochrane Collaboration data collection form for RCTs only ${ }^{[9]}$ and The Cochrane Collaboration's tool for assessing the risk of bias in randomized trials. [10]

\section{Data synthesis}

Meta-analysis difference in weighted mean was conducted using Comprehensive Meta-Analysis:

A Computer Program for Meta-Analysis, version 3.3. Where data was not available to enable pooling, a descriptive synthesis was performed.

\section{Results}

Initial database searches identified 50 nonduplicate records. 44 were excluded during the title/abstract review, 2 were excluded during the full-text review. Four studies were included in this review, of which 2 studies were included for meta-analysis. Figure 1 gives details of the study selection process.

\section{Study Characteristics}

The characteristics of included studies are given in Table 1 


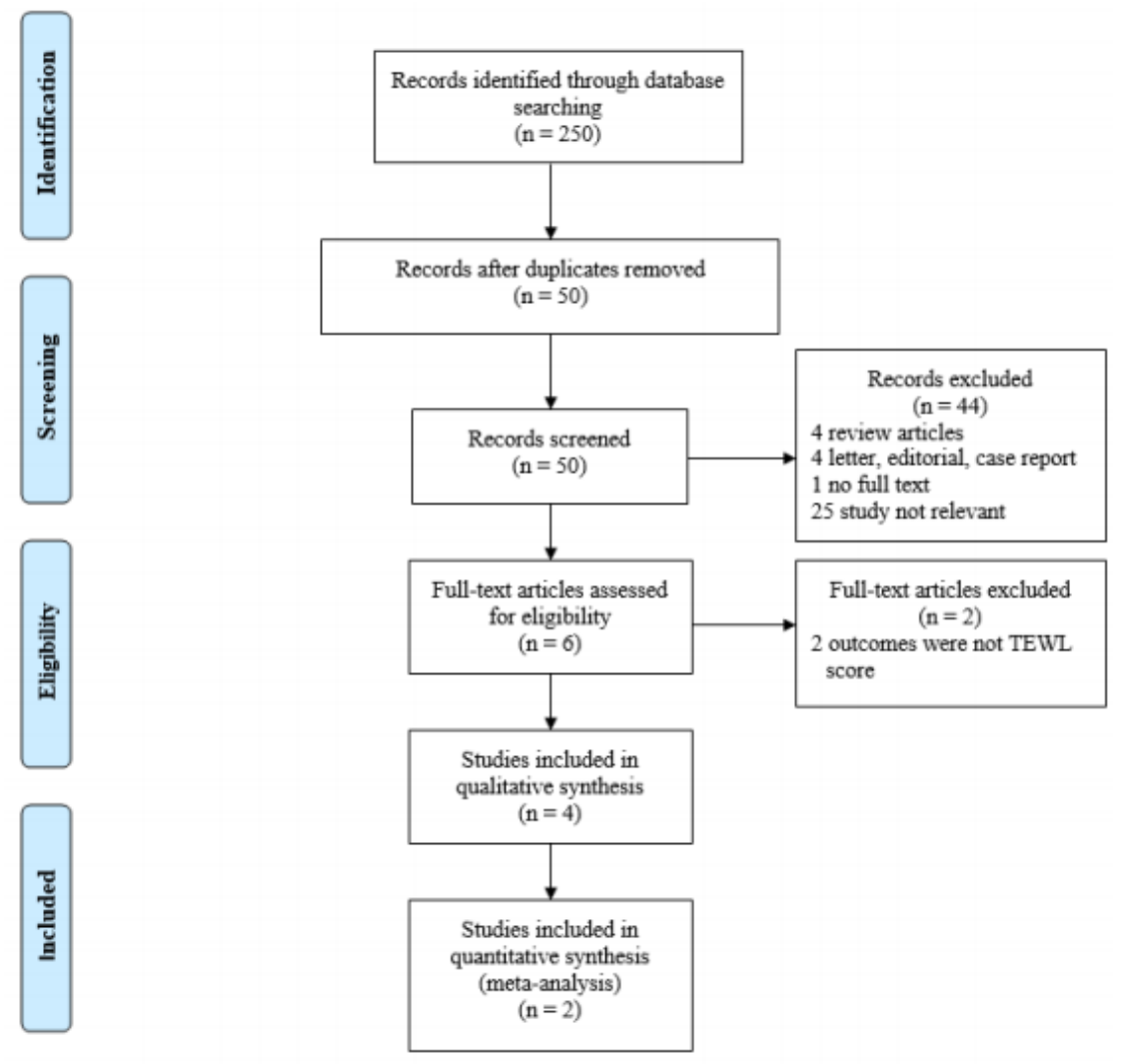

Figure 1. PRISMA flow diagram

Table 1. Characteristics of included studies

\begin{tabular}{|c|c|c|c|c|c|c|}
\hline Study & $\begin{array}{c}\text { Mean } \\
\text { age }\end{array}$ & $\begin{array}{c}\mathbf{N} \\
\text { recruited/ } \\
\text { analyzed }\end{array}$ & $\begin{array}{l}\text { Intervention } \\
\text { Group }\end{array}$ & $\begin{array}{l}\text { Comparison } \\
\text { Group }\end{array}$ & $\begin{array}{c}\begin{array}{c}\text { Duration } \\
\text { of } \\
\text { Intervention }\end{array} \\
\end{array}$ & Outcome \\
\hline $\begin{array}{l}\text { Fischer } \\
\text { et al } \\
2018^{11} \\
\text { (a) }\end{array}$ & $\begin{array}{l}67.1 \\
\text { years }\end{array}$ & $28 / 26$ & $\begin{array}{l}\text { Twice daily } \\
\text { application of } \\
\text { pH } 4 \text { water in } \\
\text { oil emulsion } \\
\text { (contained } \\
\text { glycolic acid } \\
\text { and ammonia) } \\
\text { on the forearm }\end{array}$ & $\begin{array}{l}\text { Twice daily } \\
\text { application of } \\
\text { pH } 5.8 \text { Water } \\
\text { in oil emulsion } \\
\text { (identical but } \\
\text { did not contain } \\
\text { glycolic acid } \\
\text { and ammonia) } \\
\text { on the forearm }\end{array}$ & 4 weeks & $\begin{array}{l}\text { TEWL } \\
\text { (Tewameter } \mathbb{R} \\
\text { TM300); Skin } \\
\text { roughness and } \\
\text { skin scaliness } \\
\text { (Visioscan } \mathbb{B} \\
\text { VC 98) }\end{array}$ \\
\hline (b) & $\begin{array}{l}64.5 \\
\text { years }\end{array}$ & $10 / 10$ & $\begin{array}{l}\text { Application of } \\
1 \mathrm{~mL} \text { acetone, } \\
10 \text { minutes } \\
\text { later followed } \\
\text { by application } \\
\text { of } \mathrm{pH} 4 \text { water } \\
\text { in oil emulsion } \\
\text { (contained } \\
\text { glycolic acid } \\
\text { or ammonia) } \\
\text { on the forearm }\end{array}$ & $\begin{array}{l}\text { Application of } \\
1 \mathrm{~mL} \text { acetone, } \\
10 \text { minutes } \\
\text { later followed } \\
\text { by application } \\
\text { of } \mathrm{pH} 5.8 \\
\text { water in oil } \\
\text { emulsion } \\
\text { (identical but } \\
\text { did not contain } \\
\text { glycolic acid } \\
\text { and ammonia) } \\
\text { on the forearm, } \\
\text { application of } \\
1 \text { mL acetone } \\
\text { without } \\
\text { emulsion }\end{array}$ & 24 hours & $\begin{array}{l}\text { TEWL } \\
\left.\text { (Tewameter }{ }^{\circledR}\right) \\
\text { TM300); } \\
\text { Skin-surface } \\
\text { pH (skin-pH- } \\
\text { Meter } \mathbb{B} \\
\text { PH905) }\end{array}$ \\
\hline $\begin{array}{l}\text { Blaak } \\
\text { et al } \\
2015^{12}\end{array}$ & $\begin{array}{c}87 \\
\text { years }\end{array}$ & $26 / 20$ & $\begin{array}{l}\text { Twice daily } \\
\text { application of } \\
\mathrm{pH} 4 \text { oil in } \\
\text { water } \\
\text { emulsion on } \\
\text { the body }\end{array}$ & $\begin{array}{l}\text { Twice daily } \\
\text { application of } \\
\mathrm{pH} 6 \text { oil in } \\
\text { water } \\
\text { emulsion } \\
\text { (identical) on } \\
\text { the body }\end{array}$ & 7 weeks & $\begin{array}{l}\text { TEWL } \\
\text { (TEWL } \\
\text { DermaLab®); } \\
\text { DASI; } \\
\text { Skin surface } \\
\text { pH (skin-pH- } \\
\text { Meter } \mathbb{8} \\
\text { P905); } \\
\text { Stratum } \\
\text { Corneum } \\
\text { hydration } \\
\text { (Corneometer } \\
\text { (B CM 825); } \\
\text { Micro- } \\
\text { biological } \\
\text { assessment } \\
\text { (microbial } \\
\text { culture) }\end{array}$ \\
\hline
\end{tabular}




\begin{tabular}{|c|c|c|c|c|c|c|}
\hline Study & $\begin{array}{l}\text { Mean } \\
\text { age }\end{array}$ & $\begin{array}{c}\mathbf{N} \\
\text { recruited/ } \\
\text { analyzed }\end{array}$ & $\begin{array}{c}\text { Intervention } \\
\text { Group }\end{array}$ & $\begin{array}{c}\text { Comparison } \\
\text { Group }\end{array}$ & $\begin{array}{c}\text { Duration } \\
\text { of } \\
\text { Intervention }\end{array}$ & Outcome \\
\hline $\begin{array}{l}\text { Kilic et } \\
\text { al } \\
2019^{7}\end{array}$ & $\begin{array}{l}63.4 \\
\text { years }\end{array}$ & $20 / 19$ & $\begin{array}{l}\text { Twice daily } \\
\text { application of } \\
\mathrm{pH} 4 \text { water in } \\
\text { oil emulsion } \\
\text { (contained } \\
\text { glycolic acid } \\
\text { and ammonia) } \\
\text { on the forearm }\end{array}$ & $\begin{array}{l}\text { Twice daily } \\
\text { application of } \\
\text { pH } 5.8 \text { water } \\
\text { in oil emulsion } \\
\text { (identical but } \\
\text { did not contain } \\
\text { glycolic acid } \\
\text { and ammonia) } \\
\text { on the forearm, } \\
\mathrm{pH} 4 \text { control } \\
\text { untreated and } \\
\text { pH } 5.8 \text { control } \\
\text { untreated. }\end{array}$ & 4 weeks & $\begin{array}{l}\text { TEWL } \\
\left.\text { (Tewameter }{ }^{\circledR}\right) \\
\text {; Skin surface } \\
\text { pH (Skin pH } \\
\text { meter pH } 900 \\
\text { PC); } \\
\text { Stratum } \\
\text { corneum } \\
\text { hydration } \\
\text { (Corneometer } \\
\text { (B); length } \\
\text { ICLL la } \\
\text { (TEMCM 10); } \\
\text { Number of } \\
\text { lipid content } \\
\text { (HPTLC) }\end{array}$ \\
\hline $\begin{array}{l}\text { Blaak } \\
\text { et al } \\
2017^{13}\end{array}$ & $\begin{array}{l}73.5 \\
\text { years }\end{array}$ & $23 / 23$ & $\begin{array}{l}\text { Twice daily } \\
\text { application of } \\
\mathrm{pH} 4 \text { oil in } \\
\text { water } \\
\text { emulsion on } \\
\text { the forearm }\end{array}$ & Untreated & 3 weeks & $\begin{array}{l}\text { TEWL } \\
\text { (DermaLab } \\
\text { apparatus); } \\
\text { Stratum } \\
\text { Comeum } \\
\text { hydration } \\
\text { (Corneometer } \\
\text { B CM } 825 \\
\text { apparatus); } \\
\text { Skin surface } \\
\text { pH (PH900 } \\
\text { PC skin pH } \\
\text { meter); } \\
\text { ICLL length } \\
\text { (TEM); } \\
\text { Number of } \\
\text { lipid content } \\
\text { (HPTLC) }\end{array}$ \\
\hline
\end{tabular}

All included studies were conducted in Germany $(n=4)$ between 2015 until 2019. The total sample size was 98 elderly people with a mean age of 71.1 years.

1. Fischer et al $2018{ }^{[11]}$ conducted 2 studies

(a) 26 participants were analyzed. The $\mathrm{pH} 4$ water in oil emulsion was applied to the intervention areas twice daily on the forearm and the $\mathrm{pH} 5.8$ water in oil emulsion was applied to the comparison areas twice daily on the forearm. TEWL and skin-surface roughness and scaliness were assessed before and after 4 weeks (in mean $\pm S D$ ). Both formulations reduced the TEWL score. The $\mathrm{pH} 4$ emulsion led to a significant decrease of TEWL score (day 0 and day $28 ; 6.68 \pm 2.14 \mathrm{gr} / \mathrm{h} / \mathrm{m}^{2}$ and $\left.6.29 \pm 1.33 \mathrm{gr} / \mathrm{h} / \mathrm{m}^{2}\right)$ compared to the $5.8 \mathrm{pH}$ emulsion (day 0 and day $28 ; 6.34 \pm 1,48 \mathrm{gr} / \mathrm{h} / \mathrm{m}^{2}$ and $6.54 \pm 1.32$ $\left.\mathrm{gr} / \mathrm{h} / \mathrm{m}^{2}\right)$. Both formulations also reduced the skin-surface roughness and skin scaliness, but the $\mathrm{pH} 4$ emulsion led to a significant decrease of skin scaliness (day 0 and day 28; $0.92 \pm 0.51$ and $0.55 \pm 0.20, p<0.01)$.

(b) 10 participants were analyzed. The intervention areas were applied of $1 \mathrm{~mL}$ acetone, 10 minutes later followed by application of $\mathrm{pH} 4$ water in oil emulsion on the forearm and the comparison areas were applied of $1 \mathrm{~mL}$ acetone, 10 minutes later followed by application of $\mathrm{pH} 5.8$ water in oil emulsion on the forearm, application of $1 \mathrm{~mL}$ acetone without emulsion. TEWL and skin-surface $\mathrm{pH}$ were assessed before the emulsion was applied and after 24 hours (in mean $\pm S D)$. The $\mathrm{pH} 4$ emulsion led to significant decrease of TEWL score (10 mins after acetone and 24 hours; $7.59 \pm 1.36 \mathrm{gr} / \mathrm{h} / \mathrm{m}^{2}$ and $6.4 \pm 0.98$ $\mathrm{gr} / \mathrm{h} / \mathrm{m}^{2}, \mathrm{p}<0.01$ ), while the $\mathrm{pH} 5.8$ emulsion (10 mins after acetone and 24 hours; 7.44 \pm $1.07 \mathrm{gr} / \mathrm{h} / \mathrm{m}^{2}$ and $\left.6.72 \pm 0.66 \mathrm{gr} / \mathrm{h} / \mathrm{m}^{2}\right)$ and acetone only (10 mins after acetone and 24 hours; $7.79 \pm 0.98 \mathrm{gr} / \mathrm{h} / \mathrm{m}^{2}$ and $\left.7.35 \pm 1.04 \mathrm{gr} / \mathrm{h} / \mathrm{m}^{2}\right)$. In addition to that, the $\mathrm{pH} 4$ emulsion also reduced the skin surface $\mathrm{pH}(10$ mins after acetone and 24 hours; $5.84 \pm 0.35$ and $5.66 \pm 0.44$ ), while the $\mathrm{pH} 5.8$ emulsion and acetone only did not result in significantly lower $\mathrm{pH}$. The authors concluded that application of the $\mathrm{pH} 4$ emulsion resulted in significantly decreased skin surface $\mathrm{pH}$, 
improved skin barrier function, and reduced skinsurface roughness and scaliness compared to the application of the $\mathrm{pH} 5.8$ emulsion.

2. Blaak et al $2015{ }^{[12]}$ conducted a study on 20 participants. The intervention group $(n=12)$ applied $\mathrm{pH} 4$ water in oil emulsion twice daily on the body and the comparison group $(\mathrm{n}=8)$ applied pH 5.8 water in oil emulsion. TEWL, DASI, skin-surface $\mathrm{pH}$, stratum corneum hydration, and a microbiological assessment were assessed before and after 7 weeks (in graphic and median). Significantly reduced DASI in the intervention group (before and after; 230 and $30, p=0.002$ ) and comparison group (before and after; 285 and $70, p=0.036$ ). After treatment, the skin-surface $\mathrm{pH}$ decreased specifically in the intervention group (before and after; 5.55 and 5.2, $p=0.003$ ), while the comparison group remained at baseline level (before and after; 5.75 and 5.5, $p=0.527$ ). Furthermore, a significant increase in stratum corneum hydration was only seen in the intervention group (32.1 AU and 36.1 AU, p=0.005). Evaluation of TEWL showed no significant differences between groups. The TEWL in intervention group (before and after; $4.25 \mathrm{gr} / \mathrm{h} / \mathrm{m}^{2}$ and $4.6 \mathrm{gr} / \mathrm{h} / \mathrm{m}^{2}, \mathrm{p}=0.305$ ) and in the comparison group (before and after; $4.65 \mathrm{gr} / \mathrm{h} / \mathrm{m}^{2}$ and 4.5 $\mathrm{gr} / \mathrm{h} / \mathrm{m}^{2}, \mathrm{p}=0.270$ ). The microbiological analysis is not as clear as the other outcomes. It revealed an increase in cell count in both groups. It should be carefully interpreted, and more research is needed. The authors concluded that application of the $\mathrm{pH} 4$ emulsion for 7 weeks resulted in significantly improved skin barrier function compared to the application of the $\mathrm{pH} 5.8$ emulsion.

3. Kilic et al $2019{ }^{[7]}$ conducted a study on 19 participants. The $\mathrm{pH} 4$ water in oil emulsion was applied to the intervention areas twice daily on the forearm and the $\mathrm{pH} 5.8$ water in oil emulsion was applied to the comparison group areas, control pH 4 untreated, control pH 5.8 untreated. TEWL, skin-surface $\mathrm{pH}$, stratum corneum hydration, ICLL length, and the number of lipid content were assessed before and after 4 weeks (in mean $\pm S D$ ). A slight increase in mean TEWL was observed in both $\mathrm{pH} 4$ emulsion (day 1 and day $29 ; 7.82 \pm 2.87 \mathrm{gr} / \mathrm{h} / \mathrm{m}^{2}$ and

$\left.9.24 \pm 2.76 \mathrm{gr} / \mathrm{h} / \mathrm{m}^{2}, \mathrm{p}<0.05\right)$ and $\mathrm{pH} 5.8$ emulsion (day 1 and day 29; 7.56 $\pm 2.52 \mathrm{gr} / \mathrm{h} / \mathrm{m}^{2}$ and $\left.8.54 \pm 2.1 \mathrm{gr} / \mathrm{h} / \mathrm{m}^{2}, \mathrm{p}<0.05\right)$. The $\mathrm{pH} 4$ emulsion also reduced the skin surface $\mathrm{pH}$ (day 1 and day $29 ; 5.08 \pm 0.51$ and $4.62 \pm 0,5, p<0.001$ ), while the $\mathrm{pH} 5.8$ emulsion, control $\mathrm{pH} 4$, and control $\mathrm{pH}$ 5.8 did not result in significantly lower $\mathrm{pH}$. The $\mathrm{pH} 4$ emulsion resulted in

significantly higher skin hydration (day 1 and day 29; $34.52 \pm 5.83 \mathrm{AU}$ and $37.82 \pm 5.57 \mathrm{AU}, p<0.05)$ compared to $\mathrm{pH} 5.8$ emulsion $(p=0.031)$. In addition to that, analysis of TEM showed anincreased mean length of ICLL in both emulsions, but significantly higher in $\mathrm{pH} 4$ emulsion $(\mathrm{p}=0.002)$. The $\mathrm{pH} 4$ emulsion also resulted in higher number of lipid content (day 1 and day $29 ; 17.7 \pm 2.77 \mu \mathrm{g} /$ slide and $26.72 \pm 3.52$ $\mu \mathrm{g} /$ slide, $\mathrm{p}<0.001)$ compared to $\mathrm{pH} 5.8$ emulsion (day 1 and day 29; 17.22 $\pm 2.25 \mu \mathrm{g} / \mathrm{slide}$ and $22.07 \pm 2.64 \mu \mathrm{g} / \mathrm{slide}, \mathrm{p}<0.001) .(p=0.003)$. The authors concluded that application of the $\mathrm{pH} 4$ emulsion can reacidify the skin in the elderly and resulted in significantly improved skin barrier function compared to the application of the $\mathrm{pH}$ 5.8 emulsion.

4. Blaak et al $2017^{[13]}$ conducted a study on 23 participants. The $\mathrm{pH} 4$ oil in water emulsion was applied to the intervention areas twice daily on the forearm, while the comparison areas were left untreated. TEWL, skin-surface $\mathrm{pH}$, stratum corneum hydration, ICLL length, and the number of lipid content were assessed before and after 3 weeks (in graphic and mean). The 
result, presented in charts, showed that the TEWL was significantly decreased in the intervention area compared to the comparison area $(p=0.003)$, and stratum corneum hydration was increased compared to the comparison areas $(p<0.01)$. For the measurements of skin surface $\mathrm{pH}$, there was no real change. Analysis of TEM showed an increased length of ICLL in the intervention area (day 1 and day 22; $103.79 \pm \mathrm{nm} / 1000 \mathrm{~nm}^{2}$ and $220.22 \pm \mathrm{nm} / 1000 \mathrm{~nm}^{2}$, $p=0.019$ ) and decreased length of ICLL in comparison areas. (day 1 and day 22; 103.79 \pm $\mathrm{nm} / 1000 \mathrm{~nm}^{2}$ and $\left.87.21 \pm \mathrm{nm} / 1000 \mathrm{~nm}^{2}, \mathrm{p}<0.002\right)$. The $\mathrm{pH} 4$ emulsion also resulted in an increased number of lipid content (day 1 and day 22; $27.51 \pm \mathrm{ng} /$ carrier and $38.08 \pm \mathrm{ng} /$ carrier) while the comparison area resulted in a decreased number of lipid content (day 1 and day 22; $27.51 \pm$

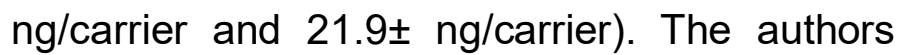
concluded that the

application of the $\mathrm{pH} 4$ emulsion can improve skin barrier function in the elderly.

\section{Risk of Bias in included studies}

Based on data on the characteristics of the study, the research articles that will be included in the meta-analysis are 2 studies, Fischer et al 2018 (a) and Kilic et al 2019 which reported the mean TEWL pre and post-treatment data in $\mathrm{pH} 4$ emulsion and non $\mathrm{pH} 4$ emulsion.

Risk of bias of the two studies included in the meta-analysis was performed using The Cochrane Collaboration data collection form for RCTs only ${ }^{[9]}$ and The Cochrane Collaboration's tool for assessing risk of bias in randomized trials. [10]

The two studies had a low risk of bias in the majority of the domains, but the risk of bias for the domains allocation concealment and blinding of participants were high in Fischer et al 2018, due to the nature of the intervention, and the risk of bias for the domain allocation concealment was unclear in Blaak et al 2015, because it was not mentioned in the research article. Overall, the quality of the included studies was high. Details of the assessment are given in Table 2 .

Table 2. Risk of bias of included studies in the meta-analysis

\begin{tabular}{lccccccc}
\hline Study & $\begin{array}{c}\text { Random } \\
\text { Sequence } \\
\text { Generation }\end{array}$ & $\begin{array}{c}\text { Allocation } \\
\text { Concealment }\end{array}$ & $\begin{array}{c}\text { Blinding of } \\
\text { participants }\end{array}$ & $\begin{array}{c}\text { Blinding of } \\
\text { outcome } \\
\text { assessment }\end{array}$ & $\begin{array}{c}\text { Incomplete } \\
\text { Data } \\
\text { outcome }\end{array}$ & $\begin{array}{c}\text { Selective } \\
\text { Reporting }\end{array}$ & $\begin{array}{c}\text { Other } \\
\text { Bias }\end{array}$ \\
\hline $\begin{array}{l}\text { Fischer } \\
e t \quad \text { al } \\
2018^{11} \\
\text { (a) }\end{array}$ & Low & high & high & low & low & low & low \\
\hline $\begin{array}{l}\text { Kilic et } \\
\text { al } 2019^{7}\end{array}$ & low & Unclear & low & low & low & low & low \\
\hline
\end{tabular}

\section{Meta-analysis}

Meta-analysis weighted mean difference of TEWL score between $\mathrm{pH} 4$ emulsion group compared to non $\mathrm{pH} 4$ emulsion found lower TEWL score in the $\mathrm{pH} 4$ emulsion group than in non $\mathrm{pH} 4$ emulsion group, with no significant difference (overall effect mean difference -0.068 , $95 \%$ confidence interval -0.485 to $0.348, p=0.11$, $\mathrm{I}^{2}=60.1$, two RCTs). (Figure 2)

The insignificant result might be due to the heterogeneity of the studies included and the limited number of studies.

\section{Discussion}

This is a systematic review and meta-analysis evaluating the efficacy of the application of $\mathrm{pH} 4$ emulsion on lowering TEWL scores in the elderly. The quality of studies included was high.

Skin care products for the elderly should contain moisturizing ingredients. However, due to the elevated skin surface $\mathrm{pH}$ in the elderly and its 
importance in maintaining skin barrier function, moisturizing products should also be formulated to normalize the skin surface $\mathrm{pH}$. TEWL is a function.

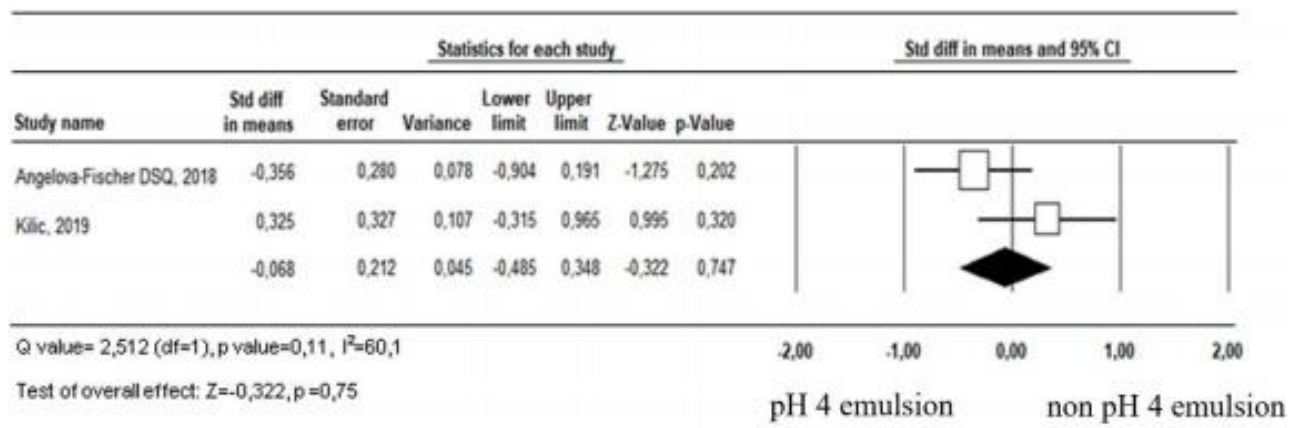

Figure 2. Forest Plot mean difference of TEWL score lowering effect of $\mathrm{pH} 4$ emulsion versus non $\mathrm{pH} 4$ emulsion

The analysis showed that both applications of $\mathrm{pH} 4$ emulsion and non $\mathrm{pH} 4$ emulsions had a lowering TEWL score effect compared to the control group. These data support the study of Moncrieff et al [14] that skin moisturizing is important to maintain normal skin barrier function.

The pooling of data using a random effects model found a lower TEWL score in the $\mathrm{pH} 4$ emulsion than in the non $\mathrm{pH} 4$ emulsion, with no significant difference. RCTs assessing the effects of $\mathrm{pH} 4$ emulsion on TEWL and other skin barrier parameters in the elderly are still needed. In addition to the TEWL score, the studies also reported other important outcomes including skin roughness and skin scaliness (Fischer et al 2018 (a)) and DASI (Blaak et al 2015), stratum corneum hydration (Blaak et al 2015, Blaak et al 2017, and Kilic et al 2019), ICLL length and lamellar organization (Blaak et al 2017 and Kilic et al 2019). The data showed that application of $\mathrm{pH} 4$ emulsion have a positive effect on those outcomes, support the literature that the $\mathrm{pH}$ of skin surface plays important role in desquamation process [2], synthesis of the intercellular lipid lamellar, and hydration of stratum corneum. [15,16]

\section{Conclusion}

The meta-analysis of the mean difference of
TEWL score lowering effect of $\mathrm{pH} 4$ emulsion versus non $\mathrm{pH} 4$ emulsion result is statistically inconclusive. This is despite the observation that the $\mathrm{pH} 4$ emulsion appears to be more effective comparatively.

The qualitative analysis found that the application of $\mathrm{pH} 4$ emulsion had improved skin barrier function in the elderly. A larger scale, welldesigned RCTs assessing the effects of $\mathrm{pH} 4$ emulsion on skin barrier function in the elderly are still needed.

\section{Acknowledgment}

The author thanks all reviewers (Dermatovenereolgy residents of Diponegoro University/Dr. Kariadi Hospital, SemarangIndonesia) for their help in collecting and analyzing data.

\section{Funding}

Nil.

\section{Conflict of Interest}

There is no conflict of interest

\section{References}

[1] UN DESA's Population Division. World Population Ageing 2019 [Internet]. United Nations. 2019. Available from: https://www.un.org/development/desa/en/news/ population/our-world-isgrowing-older.htmL

[2] Kubo A, Amagai M. Skin Barrier. In: Kang S, Amagai M, Bruckner AL, ENK AH, Margolis DJ, 
McMichael AJ, et al., editors. Fitzpatrick's Dermatology. $9^{\text {th }}$ edition. New York: McGraw-Hill Education; 2019. p. 206-31.

[3] Choi EH. Aging of the skin barrier. Clin Dermatol [Internet]. 2019;37(4):336-45. Available from: https://doi.org/10.1016/j.clindermatol.2019.04.0 09

[4] Fluhr JW, Elias PM. Stratum corneum $\mathrm{pH}$ : Formation and function of the "acid mantle." Exog Dermatology. 2002;1(4):163-75.

[5] Man MQ, Xin SJ, Song SP, Cho SY, Zhang XJ, Tu CX, et al. Variation of skin surface $\mathrm{pH}$, sebum content and stratum corneum hydration with age and gender in a large chinese population. Skin Pharmacol Physiol. 2009;22(4):190-9.

[6] Surber C, Brandt S, Cozzio A, Kottner J. Principles of skin care in the elderly. $G$ Ital di Dermatologia e Venereol. 2015;150(6):699-716.

[7] Kilic A, Masur C, Reich H, Knie U, Dähnhardt D, Dähnhardt-Pfeiffer S, et al. Skin acidification with a water-in-oil emulsion $(\mathrm{pH} 4)$ restores disrupted epidermal barrier and improves structure of lipid lamellae in the elderly. J Dermatol. 2019;46(6): 457-65.

[8] Moher D, Liberati A, Tetzlaff J, Altman DG, Altman D, Antes $G$, et al. Preferred reporting items for systematic reviews and metaanalyses: The PRISMA statement. PLoS Med. 2009;6(7).

[9] Higgins J, Thomas J. Collecting data - form for RCTs only. In: Higgins J, Thomas J, editors. Cochrane Handbook for Systematic Reviews of Interventions Version 510 [Internet]. The Cochrane Collaboration; 2011. Available from: https://training.cochrane.org/datacollectionform-rcts

[10] Higgins JPT, Altman DG, Gøtzsche PC, Jüni P, Moher D, Oxman AD, et al. The Cochrane Collaboration's tool for assessing risk of bias in randomised trials. BMJ. 2011;343(7829):1-9.

[11] Angelova-Fischer I, Fischer TW, Abels C, Zillikens D. Accelerated barrier recovery and enhancement of the barrier integrity and properties by topical application of a $\mathrm{pH} 4$ vs. a $\mathrm{pH} 5.8$ water-in-oil emulsion in aged skin. $\mathrm{Br} \mathrm{J}$ Dermatol. 2018;179(2):471-7.

[12] Blaak J, Kaup O, Hoppe W, BaronRuppert G, Langheim H, Staib P, et al. A Long-Term Study to Evaluate Acidic Skin Care Treatment in Nursing Home Residents: Impact on Epidermal Barrier Function and Microflora in Aged Skin. Skin Pharmacol Physiol. 2015;28(5):269-79.

[13] Blaak J, Dähnhardt $D$, DähnhardtPfeiffer $S$, Bielfeldt S, Wilhelm KP, Wohlfart R, et al. A plant oilcontaining $\mathrm{pH} 4$ emulsion improves epidermal barrier structure and enhances ceramide levels in aged skin. Int J Cosmet Sci. 2017;39(3):28491.

[14] Moncrieff G, Van Onselen J, Young T. The role of emollients in maintaining skin integrity. Wounds UK. 2015;11(1):68-74.

[15] Korting MSHC. The pH of the Skin Surface and Its Impact on the Barrier Function. 2006;296302.

[16] Redoules D, Tarroux R. Epidermal Enzymes: Their Role in Homeostasis and Their Relationships with Dermatoses. 1999;183-92. 